\title{
$\mathrm{N} 2 \mathrm{M} / \mathrm{C}$ 無人化への取り組み* ーリール〜ワインダー間の親巻・スプールの自動搬送
}

\author{
日本製紙株式会社 八代工場施設部 中塚 利 幸
}

\section{Try for Automatic on N 2-Machine \\ - The Jumbo Rolls and Spools Transfer between Reel and Rewinder}

\section{Toshiyuki Nakatsuka}

Yatsushiro Mill, Nippon Paper Industries Co., Ltd

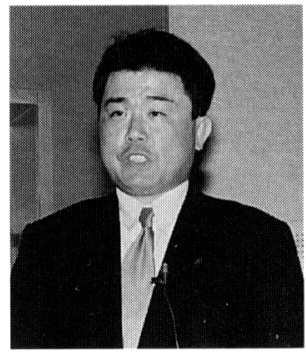

N 2-machine for newsprint was started in Feb. , 1998, at Yatsushiro mill. This machine has a lot of newest equipments, using the highest technologies. The jumbo rolls and spools handling system is one of them, and introduced into $\mathrm{N} 2-$ machine for reasons of automatically transfer.

This system has two works, the jumbo rolls are transfered by the lower guide rails from reel to rewinder, and spools are transfered by the upper guide rails from rewinder to reel. In No. 2 winder, the jumbo rolls and spools handling is carried out by Jumbo Roll Carriage which has two stages.

This system has some accessory devices as follows.

(1) Device for putting the rest paper on the spool into the pulper.

(2) Jumbo roll paper end tape applicator.

(3) Auto splice device between the jumbo rolls.

Therefore automatically transfer is realized today.

This paper describes about this handling system outlines and operating circumstances from startup.

分類： $\mathrm{O}_{4}$ 卷取 (ワインダ一), $\mathrm{M}_{10}$ リール

\section{1.はじめに}

平成 10 年 2 月より営業運転を開始した N 2 マシン は，多くの自動化設備を導入しているが，その中の 1 つに親巻自動搬送設備がある。同設備は, リール〜ワ インダー間の親卷と返還スプールの搬送を自動化した もので，親巻は下段レール上をリールからワインダー に，スプールは上段レール上をワインダーからリール

*平成 13 年度年次大会講演（講演 No. B 13）
に搬送される。

また, 平成 12 年に設置されたNo.2ワインダーと の間は，親卷搬送台車方式を導入した。同台車は，親 巻を下段に，スプールを上段に積載して搬送する 2 段 構造の台車である。

更に付带設備として, ワインダー卷上げ後のスプー ルに残った紙を自動的にパルパーに仕込む残紙処理装 置，ワインダー自動染替装置用のテープ貼り仕立機, 自動枠替装置を具備しており，これらによりリール〜 ワインダー間の親卷とスプールの搬送無人化を実現し 
ている。本稿では, 親巻白動搬送設備の設備概要と現 在までの操業状況を紹介する。

\section{2. 設 備 概 要}

2.1 マシン主仕様

1）抄 物 新聞用紙・電話帳用紙・輸出新聞用 紙

2) メーカー

ウエットパート 石川島播磨重工業製

ドライパート 三菱重工業製

カレンダーパート 淀川製鋼所製

3) 坪 量 $40 \sim 51.8 \mathrm{~g} / \mathrm{m}^{2}$

4）ワイヤ幅 $9,050 \mathrm{~mm}$

5）仕上幅 $8,130 \mathrm{~mm}$

6）抄速 設計及び常用最高 $1,700 \mathrm{~m} / \mathrm{min}$

2.2 ワインダー主仕様（No.1，No.2ワインダー 共通)

1）型＼cjkstart式 2 ドラムシャフトレスワインダ-

2) メーカー

No.1ワインダー：三菱重工業製

No.2 ワインダー：住友重機械工業製

3) 親巻取 卷径 MAX.申 3, $300 \mathrm{~mm} \times$ 紙幅 MAX. $8,290 \mathrm{~mm}$

4) 小巻取卷径 $(\phi 800 \sim \phi 1,500 \mathrm{~mm}) \times$ 紙 幅 (622 1,760 mm)

5）運転速度 設計最大 $3,000 \mathrm{~m} / \mathrm{min}$

6）スリット数 最大 10 列取

7）トリム幅 両耳最大 $670 \mathrm{~mm}$

\section{3 親巻搬送設備主仕様}

1）搬送方式 勾配による自重搬送

2）メーカー 三菱重丁.業製

3） ストッパ ショックアブソーバー方式（作動は エアーシリンダーによるリンク式)

4）レール開閉 油压シリンダー作動によるスイン グ方式

2.4 親巻搬送台車及び親巻ストレージ設備主仕様

1）搬送方式勾配による自重搬送及びリトラク 夕一方式

2）メーカー 住友重機械工業製

3） ストッパ ショックアブソーバー方式

4）移動距離 親台車： $29.3 \mathrm{~m}$ 小台車単独：5 m

5）保管本数 親卷ストレージ設備上 2 本

\section{3. 親巻搬送設備の特徵}

\section{1 レイアウト}

図 1 に親巻搬送設備・ワインダーレイアウトを示す。
1） No.1 ワインダーはマシンと同一線上, No.2 インダーはNo.1 ワインダーと並列に配置されている。

2） No.1 ワインダーへの親巻の搬送及びワインダ 一巻き上げ後のスプールのリールへの搬送は，両者を 搬送レールで結んだ親卷搬送設備で行う。

3） No.2 ワインダーへの親巻の搬送及びスプール の返送は，No. 2 親巻スタンド後に設置された親巻搬 送台車が横行しワインダー側と受渡しすることにより 行う。

4）No.2ワインダーの上流側には親巻ストレージ 設備が設置され, 2 本の親巻の保管が可能となってい る。ストレージは親巻搬送台車より親巻を受入し，ワ インダー側への払出しは台車を介して行う。

\section{2 自動搬送運転}

1）リール〜No.1 ワインダー間の親巻搬送設備は 上下 2 段構造となっており，親巻とスプールはループ 状に搬送される（図 2）。すなわち，リールから No.1 ワインダーへは親巻が下段のレール上を搬送され，ワ インダーで巻き上げ後のスプールは上段のレール上を 通りリールへ搬送される。レールは搬送方向へ下り勾 配で配置されており，親巻とスプールは各ストッパ間 を自重にて移動する。上下段レール間の移動ではリー ル部はトランスファアームとプライマリーアームの旋 回で上段から下段へ，ワインダーアンリールスタンド 部ではスプールアンローダーと呼ばれるリフティング 装置にて下段から上段に移動する。

2）ストッパ設置個所は下段を親巻スタンド，上段 をスプールスタンドと呼び, 搬送方向に沿ってNo.1, No. 2 となっている。付带設備として, ワインダー自 動枠替え装置用のテープ貼りを行う紙端仕立装置が No. 2 親巻スタンド部に，またワインダー巻き上げ後 のスプールに残った紙を自動的にパルパに仕込む残紙 処理装置がNo.2 スプールスタンド部にそれぞれ設置 されている。

3）リールから No.2 ワインダーへの親巻の搬送は, No. 2 親巻スタンド後に設置された親卷搬送台車で行 う（図 3)。親卷搬送台車は，親巻及びスプール搬送 用レールとストッパを装備しており通常 No. 2 親巻ス タンド後に待機する。

No.1 ワインダー側で親巻とスプールの搬送設備の 一部としての役目を担っている。

4）親卷搬送台車は親卷を下段に，スプールを上段 に積載して走行する(このため下段を親台車，上段を 子台車，一体の場合は親巻搬送台車と呼んでいる)。

5）No.2 ワインダーに親巻を供給する場合, 親台 車は自車のレール上ストッパ部に親卷を積載した状態 


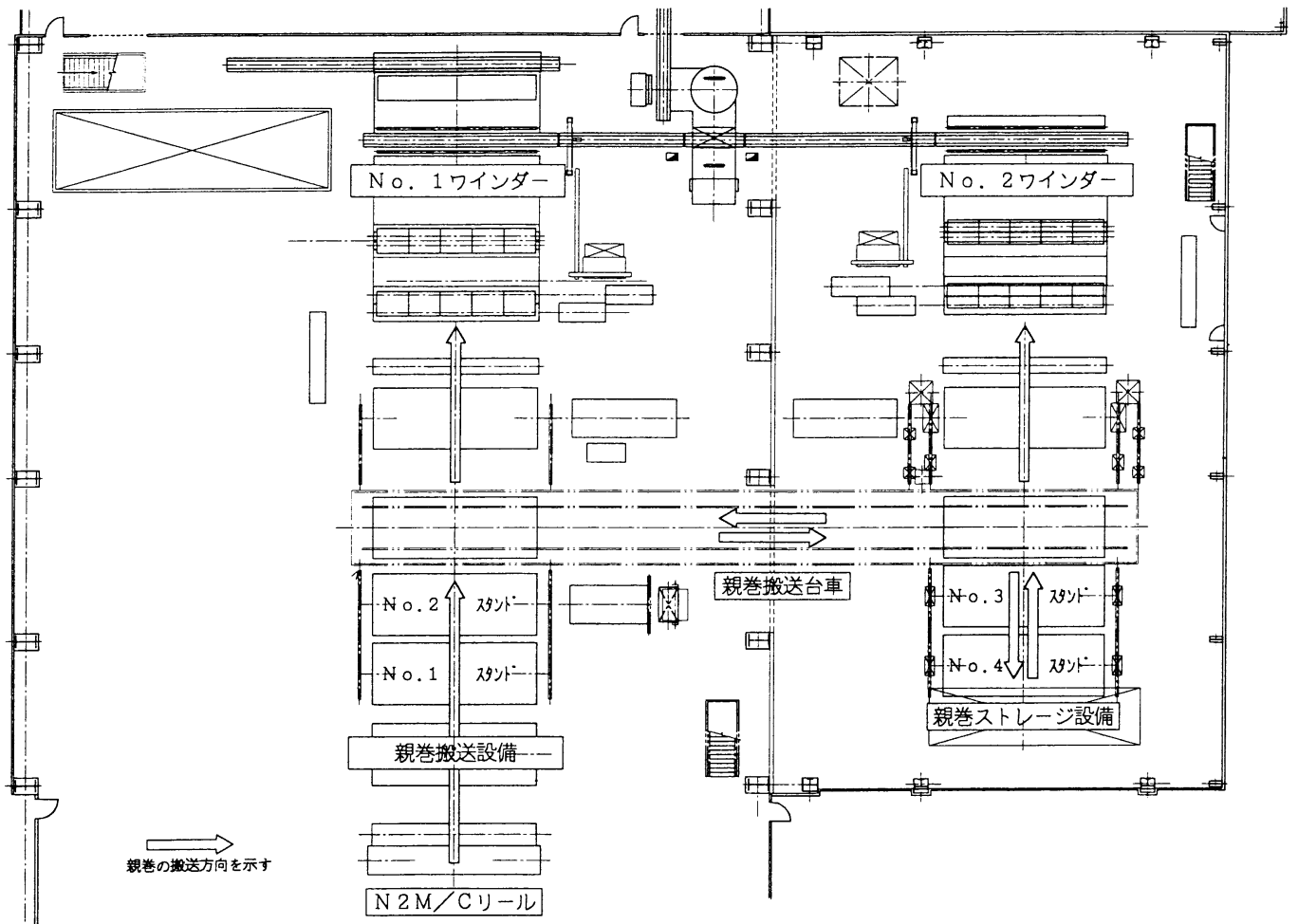

図 1 親巻搬送設備・ワインダーレイアウト

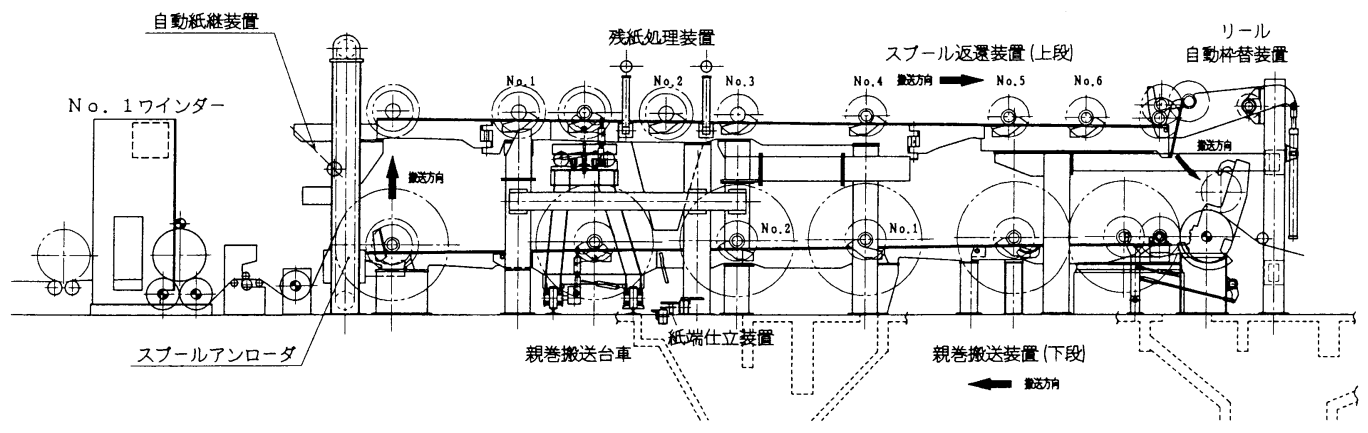

図 2 リール〜No.1 ワインダー間親巻搬送設備

でNo.2 ワインダー側に横行する。親巻搬送台車が No.2ワインダー側に到着後, 親台車からワインダー のアンワインドスタンドに親巻を払い出す。次にスプ ールアンローダー部に巻スプールがあればスプールを 受け取るために親台車上部の台車走行レールに搭載さ れた小台車が自走し，No.2 ワインダー側の上段固定 レールへ乗り移る。そして受け取り位置まで走行して スプールを受け取った後, 親台車上へ自走復帰する。

6) No.2ワインダーの上流側に親巻ストレージ設 備が設置され，新たに 2 本の親巻が保管可能となった
こと, ストレージ設備から No.1 ワインダー側への親 巻の返送が可能となったことにより, 操業安定化に役 立っている（図 4)。ストレージ設備は親巻の受け入 れ，払出しがあるため搬送方向が一方向ではない。受 入時は傾斜による自重搬送となるが，払出し方向はレ ールが登り勾配となる。このためリトラクターと呼ば れるチェーン駆動の払出専用の搬送装置を装備してい る。

\section{3 付帯設 備}

1）紙端仕立装置 


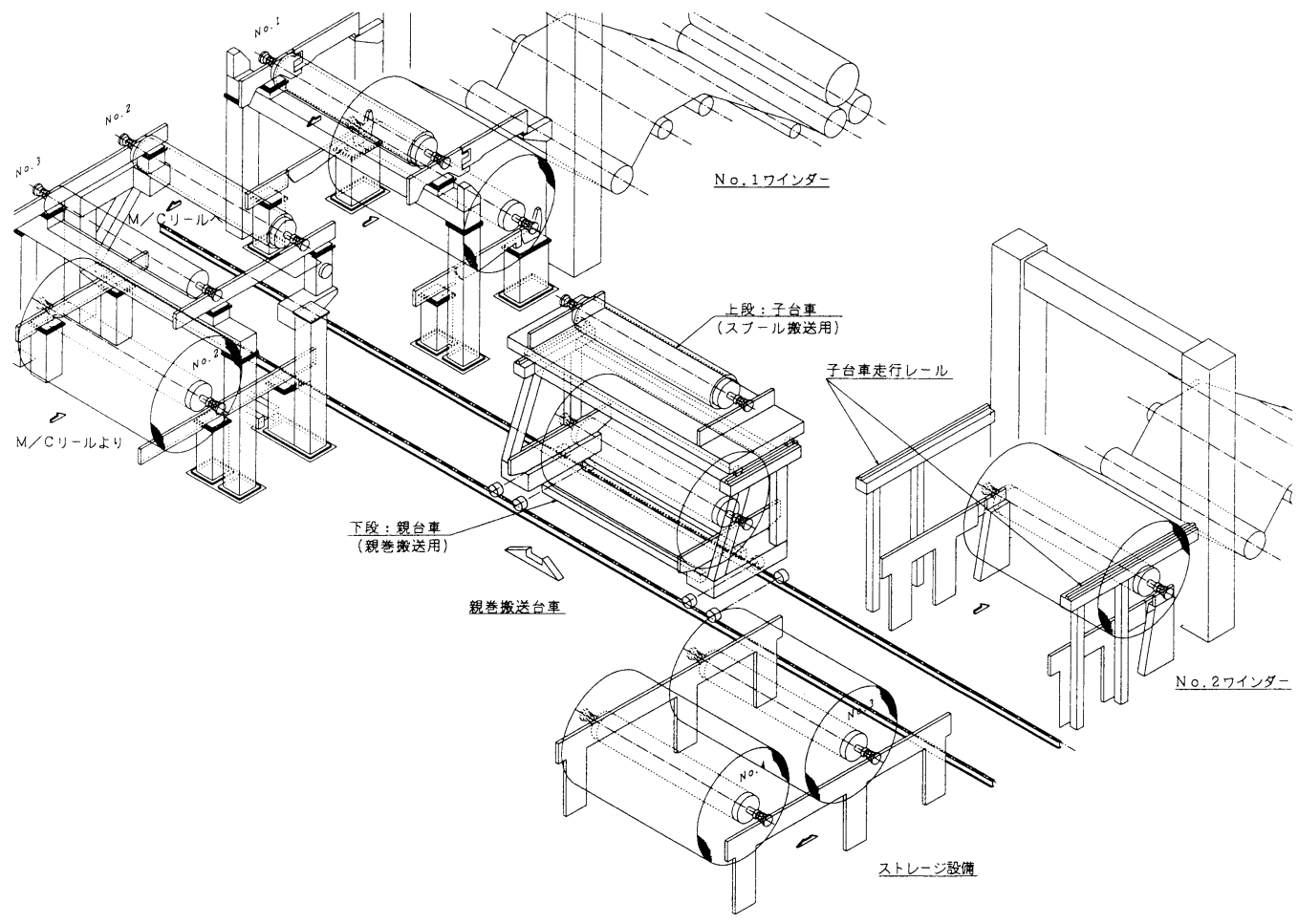

図 3 親巻搬送台車イメージ図

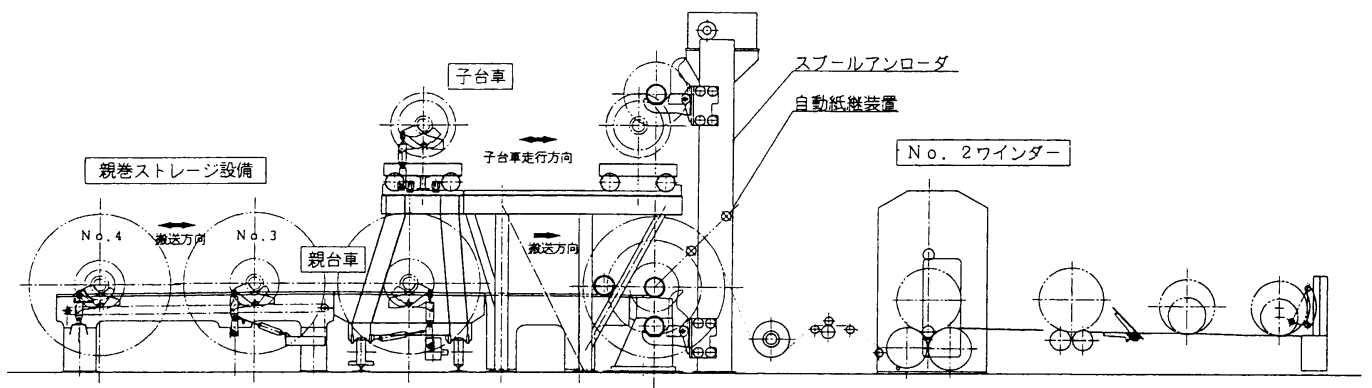

新巻䇅送台車

図 4 ストレージ設備〜No.2 ワインダー間親巻搬送設備

親巻の紙端部に白動紙継装置用の両面テープを貼り 付けする。

2) 残紙処理装置

ワインダー巻き上げ後のスプールに残った紙を，自 動的にパルパーに仕込む装置である。落とし込み時, 紙端はカーテンによりガイドされ, またスプール回転 装置が設置されている。

3）自動紙継装置

ワインダーで巻き上がったスプールをスプールアン ローダー装置で持ち上げ，新規親巻を受け入れた後， 自動紙継装置により, 両巻取の紙継ぎを行う。新規親
巻の巻端には全巾に亘り両面テープが張られており， スプライス装置はこのテープ位置を検出しプレッシャ ロールにて旧巻取のシートを押し付け接合する。接合 後, 紙継装置の全巾カッターが作動し旧巻取側のシー 卜は切断され紙継ぎが完了する。なお，紙継ぎ部は， ワインダーで巻端外層除去装置により自動除去される。

4) 安全装置

搬送装置の周囲を安全柵で囲み，装置内へ立ち入る 必要のある箇所にはゲートを設けている。ゲートには 開閉確認センサがありゲート開放時には搬送装置の作 動を制限する。又，オートロック装置も設置されてお 
り，親巻移動時や装置作動中はゲートを自動ロックし て装置内立ち入りを規制している。

\section{4. 実際の運用の中での改善点}

\section{1 自動紙継装置}

紙継ぎを行った場合, 張力が切れるときに巻取に㵣 が入り，また，スリッターナイフの部分で紙が裂けて しまい紙継ぎが失敗する状態が続いた。そこで, ワイ ンダーリードインペーパーロール下に紙押さえ装置を 設置し，自動紙継ぎ時に上昇して紙の緩みを抑え，巻 取への噭入り及び自動紙継ぎの失敗を防いでいる。

\section{2 巻端外層除去装置}

ワインダーで巻上がり後, 自動紙継ぎの継手部を巻 取外層から除去する装置であるが, 当初は, 移動式の カッターで上卷をカットする装置を導入していた。し かし, カットする枚数にばらつきが出て使いこなす事 が出来なかった。現在は, スイング開閉するクッショ ンロールのカバーに鋸刃を全巾で取り付けて巻端の紙 継テープ部のみを切除するカッティング装置としてい る。

\section{5. 効果}

\section{1 親巻搬送設備・スプール返還設備}

クレーンの操作が全く必要ないため, 時間の短縮 · 省力化につながるとともに, 安全にスプールを搬送す ることができる。

\section{2 親巻搬送台車}

No.2 ワインダーへ親巻を搬送する場合も, クレー ンを使用することなく省力化につながっている。No. 2 ワインダー側には\# $3 \cdot 4$ ストレージが設けてあり, No. 1 ワインダー側及び台車を合わせて最大 5 本の巻 取を溜めることができ，ワインダー以降のトラブル発 生時もマシンスピードを極力下げなくて済む。

\section{3 自動紙継装置}

枠替え毎の通紙作業が不要となり, 通紙時間の短縮 ・通紙時の 1 人作業が可能となった。また, 通常の手 動通紙を行うと下巻き部分でノースリットの所が発生 してしまうが，自動紙継ではその心配はない。

\section{6. 今後の課題}

\section{1 紙端仕立装置}

テープ仕立機の設置場所がパルパーの上部にあり， 環境の悪いことから機械部品が腐食し作動不良を引き 起こしている。また，仕立て後に，エアーを巻き込み 巻取の紙端が床面に落ちてしまうことがあるため，そ れを防止する仮止めテープをオペレーターが貼ってい る。今後, 機械部品の防錆対策とともに仮止めテープ 貼り装置の設置を検討している。

\section{2 巻端外層除去装置}

自動運転では, 紙が損紙ポケットに落ちないことも あり，成功率が低いためオペレーターの手動操作によ り除去している。シーケンスの変更やエアージェット の調整により自動運転できるよう対策を取りたい。

\subsection{No.2 ワインダー損紙処理}

No.2ワインダーで発生した剥き紙・損紙を処理す るために，No.1ワインダー側にある損紙パルパーま で人手で運搬している。途中, 親巻搬送台車レール上 を運搬することや移動距離が長いことからオペレータ 一には負担がかかっている。安全かつ省力化につなが る損紙搬送方法を見いだす必要がある。

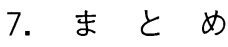

本設備により，マシンの親卷とスプールの搬送無人 化を実現した。平成 10 年の設置当初ワインダーは 1 台であり搬送設備は 1 ループであったが平成 12 年の No.2 ワインダー増設に伴い新たに独立した搬送系と の接続が必要となった。このため搬送設備の一部を 2 つの台車を上下に組み合わせた親巻搬送台車に置き換 え, 雨搬送設備を結び付ける方法を採った。この時点 でリールとワインダー間の親卷搬送・スプール返還の 搬送自動化の考え方として1つのスタイルが確立した と自負している。しかし, 本設備はその付帯設備をみ れば分かるように, 単なる搬送設備ではなく, ワイン ダーアンリール自動紙継の前処理である親巻紙端テー プ仕立てやスプールの残紙処理の问動化, 損紙処理の 省力化も目的としている。先に述べたように紙端テー プ仕立装置や巻端不良外層除去装置など，まだ人手を 要している部分がある。これらの課題を解決し完全無 人化を目指して，今後も努力して行きたい。 